\title{
Legal positivism, conventionalism, and the normativity of law
}

\section{Torben Spaak}

To cite this article: Torben Spaak (2017): Legal positivism, conventionalism, and the normativity of law, Jurisprudence, DOI: 10.1080/20403313.2017.1411116

To link to this article: https://doi.org/10.1080/20403313.2017.1411116

\section{曲 Published online: 19 Dec 2017.}

Submit your article to this journal ๔

Q View related articles $\square$

View Crossmark data $\nearrow$ 


\section{Legal positivism, conventionalism, and the normativity of law}

\section{Torben Spaak}

Department of Law, Stockholm University, Stockholm, Sweden

\begin{abstract}
The aim of this article is to see whether we can account for the normativity of law within the framework of legal positivism and whether the idea of a social convention could be of help in this endeavour. I argue, inter alia, that we should distinguish between (a) the problem of accounting for the normativity of law, conceived as a necessary property of law, and $(\beta)$ the problem of accounting for the use of normative legal language on the part of legal actors; that the debate about the normativity of law, which mainly concerns (a), is more or less identical to the debate between legal positivists and non-positivists; that one cannot account for the normativity of law, conceived along the lines of (a), within the framework of legal positivism, and that the question of the normativity of law considered within the framework of legal positivism is not an open question.
\end{abstract}

\section{KEYWORDS}

Legal positivism; conventionalism; coordination convention; constitutive convention; normativity; the concept of 'ought'; detached legal statements; Kelsen; Postema; Marmor; Raz

\section{Introduction}

Most judges and legal scholars, including philosophers of law, conceive of law as a system of rules and principles or other types of standards, and some of them - even some legal positivists, such as Jules Coleman ${ }^{1}$ and Scott Shapiro ${ }^{2}-$ also appear to believe that law thus conceived is necessarily normative. But are they right? I do not think so. As I understand it, the problem, which I shall refer to as the problem of the normativity of law, is to account for the necessary normativity of law, if there is any. The problem of the normativity of law may be somewhat difficult to grasp, however. For one thing, it is not obvious what we are to understand by 'normativity'. While everyone would agree that 'normative' has a different meaning (sense) from 'descriptive', few of us seem to have a clear idea either about the strength, or stringency, that normativity has in various contexts, including the context of law, or about whether 'normativity' has the same meaning in different fields, such as law, morality, religion, or epistemology.

The aim of this article is to investigate and see whether we can account for the normativity of law within the framework of legal positivism and whether the idea of a social convention could be of help in this endeavour. As I shall explain, I do not believe that it is possible to offer such an account; and to illustrate the difficulties involved in trying to do so, I am going to consider the accounts of the normativity of law proposed by three

CONTACT Torben Spaak torben.spaak@juridicum.su.se Department of Law, Stockholm University, Stockholm 106 91, Sweden

1Jules Coleman, The Practice of Principle (Oxford University Press 2001) 95.

${ }^{2}$ Scott Shapiro, 'Law, Plans, and Practical Reason' (2002) 8 Legal Theory 387, 389.

(c) 2017 Informa UK Limited, trading as Taylor \& Francis Group 
prominent jurisprudents, who all work in the tradition of legal positivism, namely, Hans Kelsen, Gerald Postema, and Andrei Marmor. The reason why I focus on the theory of legal positivism in this context is that I consider it to be the best theory of law on the market, and the reason why I concentrate on the idea of a social convention is that I consider conventionalism to be the most promising avenue open to legal positivists in regard to the question of the normativity of law.

I argue (A) that we need to distinguish carefully between $(\alpha)$ the problem of accounting for the normativity of law, conceived as a necessary property of law, and $(\beta)$ the problem of accounting for the use of normative legal language on the part of judges, attorneys, legal scholars, and others; (B) that the contemporary debate about the normativity of law, which mainly concerns $(\alpha)$, is in substance, if not in form, more or less identical to the old debate between legal positivists and non-positivists; (C) that one simply cannot account for the normativity of law, conceived along the lines of $(\alpha)$, within the framework of legal positivism, whether or not one invokes the idea of a social convention, and that the problem of the normativity of law thus conceived and considered within the framework of legal positivism, is not an open, and therefore not a very interesting, legal-philosophical question; (D) that the important question for a legal positivist is whether a given legal order (or legal system) is in fact normative, in roughly the sense of justified (or authoritative) normativity (a notion to be explained below), and that to determine whether this is so, one needs to consider the content and the administration of this legal order; and (E) that the idea of conditional normativity, or normativity from a point of view, although of considerable interest when discussing $(\beta)$, is of little or no interest to those who are concerned with ( $\alpha$ ). As regards claim (C), I argue, more specifically, (C1) that Kelsen's theory of the basic norm offers no solution to $(\alpha)$, because it offers nothing more than normativity from a point of view, and that it is better understood as aiming to solve $(\beta)$; $(C 2)$ that Gerald Postema's coordination convention account, although in many ways a very fine account, cannot generate obligations for the citizens, as distinguished from the legal officials; and (C3) that Andrei Marmor's constitutive convention account, which capitalises on the idea of conditional normativity, does not and cannot take things further than Kelsen's basic-norm account does.

En route to establishing claims (A) to (E), I also argue (i) that we should think of the concept of a legal 'ought' as having the function of connecting grounds (or conditions) and consequences in legal norms and of the import of the concept of ought (roughly, the meaning of the word 'ought') as being the same in different fields; (ii) that we should distinguish between different grades (or degrees) of normativity; (iii) that the most interesting grade of normativity when discussing $(\alpha)$ is what Joseph Raz has called justified normativity; and (iv) that we may think of moral philosopher David Copp's notion of authoritative normativity as an illuminating specification of the somewhat loose idea of justified normativity.

I begin by discussing the difference between analysing a concept and identifying essential properties of the object/property that falls under the concept (Section 1). I then proceed to consider the question of the import and function of the concept of a legal 'ought' (Section 2), the distinction between justified and social normativity (Section 3), and a way to specify the import of the concept of justified normativity (Section 4). Next, I consider Kelsen's theory of the basic norm (Section 5) and Joseph Raz's interpretation of the theory of the basic norm in terms of the concept of a detached normative 
statement (Section 6). Having done that, I turn to consider two conventionalist accounts of the normativity of law, namely, Gerald Postema's coordination convention and Andrei Marmor's constitutive convention account, respectively (Sections 7-8). The article concludes with a brief discussion of the idea of conditional normativity, or point-of-view normativity, and the relation between the contemporary debate about the normativity of law and the old positivism/non-positivism debate (Section 9).

\section{Conceptual analysis and essential properties}

One (but not the only) way of understanding the enterprise of inquiring into the nature of law is to conceive of it as an analysis of the concept of law. ${ }^{3}$ On what I shall refer to as the classical conception of conceptual analysis, ${ }^{4}$ the analysis of a concept aims to establish an analytically true equivalence between analysandum (that which is to be analysed) and analysans (that which does the analysing). That is to say, the task of the analyst is to find properties that are individually necessary and jointly sufficient for $X$ to qualify as law, and the type of necessity involved is that of conceptual - as distinguished from metaphysical, or 'natural', or some other type of - necessity. ${ }^{5}$

Note here that to speak of necessary conditions for the applicability of a concept, such as the concept of law, is not to assume the existence of essential properties in the sense that essentialists do when they maintain that certain objects have essential properties. That is to say, we must distinguish between (i) saying that a property of law, $p$, is necessary for the applicability of the concept of law and (ii) saying that $p$ is an essential property of law, the object. The distinction I have in mind is thus the one between de dicto necessity and de re necessity, that is, between the claim that it is necessary for law to be normative, say, in order for it to qualify as law, or $\square \forall \mathrm{x}(\mathrm{Lx} \supset \mathrm{Nx})$, and the claim that the object law is necessarily (or essentially) normative, or $\forall \mathrm{x}(\mathrm{Lx} \supset \square \mathrm{Nx}){ }^{6}$ In the former case, the necessity pertains to the claim about law (dictum), in the latter it pertains to the object law (res).

To see that (i) and (ii) are different claims might be a bit difficult when one is concerned with abstract objects, such as legal orders (legal rights, legal duties, etc.), however, because the difference between the concept of law (or a legal right, etc.), on the one hand, and law (or a legal right, etc.), on the other, is not as clear and obvious as the difference between, say, the concept of a horse and a horse. For example, could law have been something other than a set, or a system, of norms - say, human behaviour - and still have been law? I do not think so. Consider by way of comparison the case of Smith, who is a bachelor. Although it is necessary that Smith be an adult unmarried man in order for him to qualify as a

\footnotetext{
${ }^{3}$ See e.g. HLA Hart, The Concept of Law (Clarendon Press 1961) ch 1; Joseph Raz, The Authority of Law (2nd edn, Oxford University Press 2009) 18-24 (first published 1979); Robert Alexy, 'On the Concept and Nature of Law' (2008) 21 Ratio Juris 281.

${ }^{4} \mathrm{CH}$ Langford, 'The Notion of Analysis in Moore's Philosophy' in PA Schilpp (ed), The Philosophy of GE Moore (Northwestern University Press 1942) 319-42; Ernest Sosa, 'Classical Analysis' (1983) 80 The Journal of Philosophy 695; Colin McGinn, Truth by Analysis: Games, Names, and Philosophy (Oxford University Press 2012) 4-5, 14.

${ }^{5}$ Frank Jackson rejects the distinction between conceptual and metaphysical necessity (or possibility), arguing that it is the same type of necessity in both cases and that the only difference between these two types of necessity is to be found on the epistemological level: Frank Jackson, From Metaphysics to Ethics: A Defence of Conceptual Analysis (Oxford University Press 1998) 67-86. I shall, however, allow myself to assume that we can coherently distinguish between different types of necessity.

${ }^{6}$ Here $\square$ means 'is necessary', $L$ means 'is law', and $N$ means 'is normative' For more on de dicto necessity and de re necessity, see e.g. AC Grayling, An Introduction to Philosophical Logic (3rd edn, Blackwell 1997) 53-55; James W Garson, Modal Logic for Philosophers (2nd edn, Cambridge University 2013) 407-13.
} 
bachelor, that is, in order for him to fall under the concept of a bachelor, one is hardly tempted to believe that being a bachelor is an essential (necessary) property of Smith. For it is easy to conceive of a situation in which Smith lacks the property of being an unmarried man, perhaps by being a teenager or a married man. That is to say, it is easy to think of Smith as a stable and enduring object who might have had certain other properties than he in fact has. What, one may reasonably ask, is the underlying object law (or a legal right) that could have such and such properties, as the case may be? I conclude that it is better to focus an inquiry into the nature of law, including an inquiry into the normativity of law, on the necessary (and sufficient) conditions for something to qualify as law than on the essential (or necessary) properties of the object law itself.

\section{The import and function of the concept of a legal ought}

Following Kelsen, ${ }^{7}$ I conceive of the function of the concept of a legal ought as that of connecting the consequence with the condition(s) in a legal norm. Having objected to the view of (what he refers to as) traditional legal scholars, namely, that law comprises an ethical minimum, and that this means that the legal 'ought' becomes a species of moral 'ought', Kelsen proceeds to offer a reconstruction of the concept of a legal norm, in which this concept is completely severed from its source, the concept of a moral norm. He does this by conceiving of the legal norm not as an imperative, but as (what he calls) a hypothetical judgment that connects legal conditions (or legal grounds) and legal consequences precisely by means of the concept of ought: it ought to be that if $A$, then $B$, that is, $\mathrm{O}(\mathrm{A} \supset \mathrm{B}) .^{8}$ As he sees it, the legal 'ought' is a relative a priori category with the help of which we can comprehend the legal data by normatively connecting legal consequences with legal conditions:

Expressing this connection, termed 'imputation', and thereby expressing the specific existence, the validity, of the law - and nothing else - is the 'ought' in which the Pure Theory of Law represents the positive law. That is, 'ought' expresses the unique sense in which the material facts belonging to the system of the law are posited in their reciprocal relation. In the same way, 'must' expresses the law of causality. ${ }^{9}$

While I do not wish to argue that the concept of ought in a legal context is a relative $a$ priori category in Kelsen's sense, I find it illuminating to conceive of the function of this concept in the context of law as that of connecting grounds (or conditions) and consequences in norms. And this in turn means that in order to account for the normativity of law, we need to be clear about the precise meaning (sense) of the term 'ought' in legal norms, that is, about the precise sense in which conditions and consequences are connected in legal norms.

The question of the meaning of 'ought' and other central normative terms has been discussed on and off in the history of legal philosophy. Some legal philosophers, typically legal positivists, maintain that central normative terms such as 'ought', 'right', and 'duty' have a special legal meaning, which differs from the meaning they have in a

\footnotetext{
${ }^{7}$ Hans Kelsen, Introduction to the Problems of Legal Theory (Bonnie Litschewski Paulson and Stanley L Paulson tr, Oxford University Press 1992) 22-23 (first published 1934 in German under the title Reine Rechtslehre. Einleitung in die rechtswissenschaftliche Problematik by Franz Deudicke, Vienna).

8 ibid 23.

${ }^{9}$ ibid 23-24 (footnotes omitted).
} 
moral context. ${ }^{10}$ Whereas the moral meaning of the term 'ought' is taken to be normative, the legal meaning of 'ought' is usually taken to be descriptive in one way or another or, sometimes, to be normative, albeit in a way that differs from the meaning it has in a moral context. For example, Justice Holmes maintains that having a legal duty means that one is likely to suffer disagreeable consequences, if one does not do what one is legally required to do. ${ }^{11}$ Kelsen, on the other hand, maintains that whereas the concept of a moral duty coincides with the concept of a moral 'ought', the concept of a legal duty does not coincide with the concept of a legal 'ought'. ${ }^{12}$ For, he explains, a person, $p$, has a legal duty to perform an action, $\varphi$, if (and only if) there is an organ, $O$, that ought to apply a sanction to $p$ if $p$ omits to perform $\varphi$, and this means that $\varphi$ need not be an action that $p$ ought to perform. And Hart defends (what we might call) a relativistic account of the meaning of the term 'legal obligation' (or 'legal duty'), according to which a (n internal) statement that a person has a legal obligation refers to an action that is 'due from or owed by' the person having the obligation, in the sense that it 'may be properly demanded or extracted from him according to legal rules or principles regulating such demands for action'.13

Neil MacCormick takes a different view, however. He is explicit that the normative terms in question have the same meaning in legal as in moral contexts. Having argued that although legal and moral rights and obligations are conceptually distinct, he points out that it does not follow that the nouns 'right' and 'obligation' have different meanings when qualified by the adjectives 'legal' and 'moral', respectively:

Whatever differentiates legal obligations from moral obligations, it is not ... some kind of pun on the term 'obligation'. But in my suggestion ... the differentiation arises from justifying grounds of ascription of legal and of moral right and duty, the former being jurisdictionally relative while the latter are not. ${ }^{14}$

I am inclined to agree with MacCormick that it is preferable to distinguish between legal and moral rights and obligations not on the basis of the meaning of the relevant terms, but on the basis of the reasons why a certain right or obligation is a legal, or moral, right or obligation. On this analysis, there is only one sense of normativity, only one sense of 'ought', and this means that there is no specifically moral or legal or prudential type of normativity, but only normativity plain and simple. And, as I see it, the relevant sense of the words 'normative' or 'normativity' is (roughly) the sense of justified (or authoritative) normativity, outlined in Sections 4-5 below.

\footnotetext{
${ }^{10}$ On this, see Raz, The Authority of Law (n 3) 37-38; Luís Duarte D'Almeida, 'Legal Statements and Normative Language' (2011) 30 Law and Philosophy 167.

${ }^{11}$ Oliver Wendell Holmes, 'The Path of the Law' (1896/1897) 10 Harvard Law Review 457, 461.

${ }^{12}$ Hans Kelsen, General Theory of Law and State (Anders Wedberg tr, The Lawbook Exchange 1999) 60 (first published by Harvard University Press 1945).

${ }^{13} \mathrm{HLA}$ Hart, Essays on Bentham (Clarendon Press 1982) 159-60. One may well wonder precisely how this view of the meaning of legal and moral terms is compatible with Hart's non-cognitivism (or expressivism). But perhaps the answer is that Hart is a hybrid non-cognitivist in the sense proposed by Joseph Raz and Kevin Toh, respectively. See Joseph Raz, 'HLA Hart (1907-1992)' (1993) 5 Utilitas 145; Kevin Toh, 'Hart's Expressivism and His Benthamite Project' (2005) 11 Legal Theory 75, 85-91; Kevin Toh, 'Raz on Detachment, Acceptance and Describability' (2007) 27 Oxford Journal of Legal Studies 403, 404-406. Note, however, that Raz and Toh attribute slightly different versions of hybrid non-cognitivism to Hart.

${ }^{14}$ Neil MacCormick, 'Comments' in Ruth Gavison (ed), Issues in Contemporary Legal Philosophy: The Influence of HLA Hart (Oxford University Press 1987) 105-13, 108.
} 
The view that there is only one sense of 'ought' is shared by a number of contemporary moral philosophers. Judith Jarvis Thomson, ${ }^{15}$ for example, maintains that 'ought' means the same in different contexts but points out that whereas the moral 'ought' is categorical, other 'oughts' are conditional upon the will on the part of the agent to achieve a certain end. She introduces an example in which Alfred has noticed that Smith will lose a chess game unless he moves the rook and has concluded that Smith ought to move the rook, and in which Bert has noticed that Smith will cause the deaths of hundreds of people if he moves the rook and has concluded that Smith ought to refrain from moving the rook. The correct way to conceive of the situation, Jarvis Thomson explains, is to say that 'ought' means the same in both cases, though the latter (moral) 'ought' is categorical, whereas the former (chess) 'ought' is conditional upon a will to win the game.

The reason why Jarvis Thomson insists that the chess 'ought' is conditional is, of course, precisely that she holds that 'ought' has the same meaning in different contexts - if she had held that both the moral 'ought' and the chess 'ought' are categorical, she would have had to admit that Alfred and Bert are contradicting each other, which does not seem to be the case. And if the legal 'ought' has the same meaning as the moral 'ought', and if one nevertheless wishes to hold that (internal) legal statements are not (internal) moral statements, one must conceive of such statements as being conditional in Jarvis Thomson's sense (or as being detached in Raz's sense: see Section 7 below) - if one does not, (internal) legal statements will become a species of (internal) moral statements, in contradiction of the separation thesis.

I should like to conclude this section by pointing out that the idea behind the view of some legal positivists, that the legal 'ought' has a specifically legal meaning - that is, that such an account is needed to avoid turning internal legal statements into internal moral statements - has no bearing on the debate about the normativity of law, conceived as a debate about the necessary properties of law. Clearly, a legal positivist may coherently maintain that the agent ought legally to do $X$, in the sense, say, that his doing $X$ can be properly demanded of him according to legal rules and principles. But the question that is of interest to those who debate the normativity of law is not whether the agent is legally obligated in this weak, relativistic way, but whether the relevant rules and principles themselves have justified normativity, that is, whether they require categorically that the agent do $X$; and to discuss this latter question we need to focus on the general (moral) meaning of 'ought'. If all one wants to do, is to account for the use of normative terms in internal legal statements, one might well rest content with the Hartian view that these terms have a specifically legal meaning that differs from their moral meaning. As I shall explain below (in Section 7), following Raz, we might refer to such an account as a belief-based, as distinguished from a validity-based, account of the normativity of law.

\section{Justified and social normativity}

To see that normativity is a significant property of law, we may note to begin with that holding that law is necessarily normative and that legal concepts like 'ought', 'duty' and

\footnotetext{
${ }^{15}$ Judith Jarvis Thomson, 'Normativity' in Russ Schafer-Landau (ed), Oxford Studies in Metaethics: Volume 2 (Oxford University Press 2007) 240-65, 242.
} 
'right' thus have a necessary normative import, in the sense that having a duty (or a right) means that one ought to or may or may not do something, is to reject the well-known view, espoused especially by some legal realists, that a person has a legal duty if, and only if, he is likely to suffer disagreeable consequences if he does not do what he is required to do. For this so-called predictive analysis completely does away with the normative import of the concepts in question. ${ }^{16}$

Consider now John Austin's claim, that a person has a legal duty to perform a certain action if, and only if, he has been commanded by the sovereign to do so: 'Being liable to evil from you if I comply not with a wish that you signify, I am bound or obliged by your command, or I lie under a duty to obey it. ${ }^{17}$ What does this mean? Well, one might be tempted to argue that whereas Holmes's analysis completely drains the relevant concepts of normative content, Austin's analysis supplies them with at least some normative content, albeit rather weak and uninteresting. The idea would be that maintaining that a person has a legal duty to do $X$ if, and only if, he has been commanded by the sovereign to do $X$ is not to say that $X$ will be (or is likely to be) performed, but that $X$ is (in some sense) required.

I am not, however, convinced that there is much difference between the two analyses. Thus, one might ask, does Austin mean that a person has a legal duty, who has been commanded by the sovereign, whether or not he is also likely to suffer disagreeable consequences if he does not do what he was commanded to do, or does he mean instead that a person has a legal duty, who is likely to suffer disagreeable consequences if he does not do what he was commanded to do, and is there an interesting difference between the two alternatives? I am inclined to think that Austin's analysis implies Holmes's analysis (analytically, if not logically), but not vice versa. For, on Austin's analysis, the sovereign would not be the sovereign if he were not habitually obeyed by the bulk of the population, that is, if he could not enforce his commands; and this appears to mean that, necessarily, if a person has been commanded by the sovereign, he will likely suffer disagreeable consequences if he does not do what he was commanded to do.

Let us, however, assume, for the sake of the argument, that there is a difference between the two analyses, and that the difference is that something that has the property of being a legal duty also has (the second-order) property of being normative at least to some extent on Austin's analysis but has no such property at all on Holmes's. Nevertheless, both Kelsen ${ }^{18}$ and Hart ${ }^{19}$ have objected to Austin's analysis, that it cannot account for the normativity of law. Hart, for example, complains that the analysis neglects the distinction between being obligated to do something and being obliged (or forced) to do it. To bring out the inadequacy of Austin's analysis, he considers a situation in which a person is ordered by a gunman to hand over his money. As Hart sees it, the victim may be obliged - but will not be obligated - to hand over the money, and he points out that what is missing in Austin's theory is the idea of a rule. ${ }^{20}$ We need the idea of a

\footnotetext{
${ }^{16}$ Note that the reference in the analysis to disagreeable consequences needs to be a reference not to what is a disagreeable consequence, but to what is commonly perceived to be disagreeable consequences among the people concerned, in order to avoid incorporating a (genuine) normative element into the analysis.

${ }^{17}$ John Austin, The Province of Jurisprudence Determined and The Uses of the Study of Jurisprudence. With An Introduction by HLA Hart (Hackett 1998) 14 (previously published by Weidenfeld \& Nicholson in 1954; first published 1832).

${ }^{18}$ Kelsen, General Theory (n 12) 31-32.

${ }^{19} \mathrm{Hart}$, The Concept of Law (n 3) 79-88.

${ }^{20}$ ibid 79-88.
} 
rule in our analysis of the concept of a legal obligation, he says, ${ }^{21}$ for to say that someone has an obligation to perform an action is to say that he is required by a rule to perform that action.

On Hart's analysis, the foundation of the normativity of law is to be found in the rule of recognition, which Hart conceives of as a social rule and, more specifically, a conventional judicial customary rule. Social rules, Hart explains, have an internal aspect, in addition to the external aspect that they share with habits and which consists in a certain regularity of behaviour. $^{22}$ Accordingly, his account of the normativity of social rules centres on this internal aspect, or more specifically, on the characteristic pro-attitude towards the relevant pattern of behaviour among those concerned, which he refers to as the internal point of view. And he describes the internal point of view as 'a critical reflective attitude to certain patterns of behaviour as a common standard', which attitude displays itself in criticism of deviant behaviour and in recognition that such criticism is justified, etc. ${ }^{23}$

As we have seen (in Section 1), Hart holds that an internal statement that a person has a legal obligation refers to an action that is 'due from or owed by' the person having the obligation, in the sense that it 'may be properly demanded or extracted from him according to legal rules or principles regulating such demands for action'. ${ }^{24}$ On this analysis, says Hart, when a judge states that someone has a legal obligation to pay his taxes, say, he may mean to 'speak in a technically confined way', that is, he may mean to speak from within a legal institution that he is committed as a judge to maintaining; and in so doing he is drawing attention to what is legally demanded of the person having the obligation. ${ }^{25}$ And although the judge may well morally approve of this obligation, his moral approval is not part of the meaning of his legal statement. ${ }^{26}$

But, one wonders, is there really an important difference as regards the respective strengths of Hartian and Austinian normativity? To be sure, whereas Austin analyses the concept of a legal rule in terms of the concept of a command, Hart substitutes the concept of a (social) rule for the concept of a command and analyses the concept of a (social) rule in turn partly in terms of the concept of the internal point of view. But he also holds that the internal point of view need not be a moral point of view, ${ }^{27}$ and this suggests that the difference between normativity grounded in (social) rules and normativity grounded in commands is rather insignificant. If, however, there is a difference, it must surely be that law is normative in a more demanding way on Hart's analysis than it is on Austin's.

In any case, most of those who concern themselves with the question of the normativity of law have something more demanding in mind than does Hart, and I take this to be what Raz calls justified normativity, or something very much like it. According to this conception of normativity, a legal standard qualifies as a norm only if it is justified:

Two conceptions of the normativity of law are current. I will call them justified and social normativity. According to the one view legal standards of behaviour are norms only if and

\footnotetext{
${ }^{21}$ ibid 83.

${ }^{22}$ ibid $54-56$.

${ }^{23}$ ibid 56.

${ }^{24}$ Hart, Essays on Bentham (n 13) 159-60.

${ }^{25}$ ibid 266.

${ }^{26}$ ibid.

${ }^{27}$ Hart, The Concept of Law (n 3) 198-9.
} 
in so far as they are justified. They may be justified by some objective and universally valid reasons. They may be intuitively perceived as binding or they may be accepted as justified by personal commitment. On the other view standards of behaviour can be considered as norms regardless of their merits. They are social norms in so far as they are socially upheld as binding standards and in so far as the society involved exerts pressure on people to whom the standards apply to conform to them. Natural law theorists characteristically endorse the first view, positivists usually maintain the second view. ${ }^{28}$

To clarify further the import of the two conceptions of normativity, Raz points out that whereas a person who operates with the conception of social normativity (and considers law to be necessarily normative) will consider it an open question whether the citizens have an obligation to obey the law, a person who operates with the conception of justified normativity (and considers law to be necessarily normative) will hold that it follows that the citizens have an obligation to obey the law. ${ }^{29}$

Raz also points out that Hart operates with a conception of social normativity, whereas Kelsen operates with a conception of justified normativity. ${ }^{30}$ And this seems right to me. As we shall see below (in this section), Hart's convention-based account of the normativity of law does not have the resources to establish, not does it appear to be aimed at establishing, a justified normativity of law. And introducing a distinction between a subjective and an objective 'ought', Kelsen explains that only acts of will that express an objective 'ought' can properly be called norms. The idea is that an action, $\varphi$, is such that an agent, $A$, objectively ought to perform $\varphi$ if, and only if, $A$ ought to perform $\varphi$ not only from the point of view of the norm giver, $B$, but also from the point of view of a disinterested third party, $C .^{31}$

I believe, as I have said, that there is general agreement among legal philosophers that something like justified normativity is, and should be, at the centre of the debate about the normativity of law. I share this view. That law is necessarily normative in the social sense is clear, at least on a legal positivist analysis, which emphasises the social efficacy of law; but it is not very interesting. The question of whether law is necessarily normative in the sense of justified normativity, on the other hand, is of considerable interest. For this is the question of whether it is in the nature of law to obligate. What this means, then, is that Hart's account of the normativity of law does not appear to be aimed at the same problem as the accounts put forward by many other legal philosophers. However, this is by no means a novel observation; it has been pointed out by, among others, Raz, ${ }^{32}$ Moore, ${ }^{33}$ Toh, ${ }^{34}$ Bix, ${ }^{35}$ and Rodriguez-Blanco. ${ }^{36}$

However, although I find the idea of justified normativity proposed by Raz suggestive, I also find it somewhat unclear. To gain a better understanding of what is involved in the ascription of justified normativity to a standard, we may benefit from David Copp's subtle discussion of the property of being normative, which includes a distinction

\footnotetext{
${ }^{28}$ Raz, The Authority of Law (n 3) 134.

${ }^{29}$ ibid 137.

${ }^{30}$ ibid 134.

${ }^{31}$ Hans Kelsen, Reine Rechtslehre (2nd edn, Franz Deudicke 1960) 7.

${ }^{32}$ Raz, The Authority of Law (n 3) 134.

${ }^{33}$ Michael S. Moore, Educating Oneself in Public (Oxford University Press 2000) ch 3.

${ }^{34}$ Toh, 'Hart's Expressivism' (n 13) 77.

${ }^{35}$ Brian H Bix, 'Legal Positivism and "Explaining" Normativity and Authority' (2006) 5 APA Newsletter on Philosophy and Law 5, 6-7.

${ }^{36}$ Veronica Rodriguez-Blanco, 'Social and Justified Normativity: Unlocking the Mystery of the Relationship' (2012) 25 Ratio Juris 409, 411.
} 
between (what Copp refers to as) three distinct grades of normativity, namely, generic, motivational, and authoritative normativity. I shall argue that we may view Copp's account of authoritative normativity as one way of specifying the notion of justified normativity.

\section{Justified normativity conceived as authoritative normativity}

In an attempt to defend ethical naturalism, David Copp considers and rejects the objection to such naturalism, that it cannot account for the normativity of morality. ${ }^{37}$ His strategy is to distinguish (what he refers to as) three grades of normativity of increasing strength or stringency, and to consider, first, the question of whether morality can be said to have one or more of these three grades of normativity, and second, the question of whether ethical naturalists can account for the fact (assuming it is a fact) that morality has that or those particular grades of normativity. His own position is that morality simply does not have the strongest type of normativity, which he calls authoritative normativity, and that it is therefore not a problem that ethical naturalism cannot account for such normativity.

Beginning with the first grade of normativity, which he labels 'generic normativity', Copp points out that moral, prudential, and epistemological claims have 'a characteristic essential semantic connection to decisions about action or choice', and that we may use the term 'normative' to refer to this connection. ${ }^{38}$ Turning to consider the second grade of normativity, he points out that one may well think that morality is normative in a deeper way than, say, rules of etiquette, in the sense that whereas a person who does not care about moral requirements appears to be in some sense irrational, this cannot be said of a person who does not care about the rules of etiquette. He therefore proposes that morality, but not rules of etiquette, has 'motivational normativity' in the sense that necessarily, a practically rational person will be motivated to act in accordance with what he recognises as all-things-considered and relevant moral requirements. ${ }^{39} \mathrm{He}$ points out, however, that motivational normativity is not to be confused with what is usually referred to as motivational internalism, according to which, necessarily, a person who believes he is morally required to act in a certain way will be motivated to act in that way. ${ }^{40}$ The latter, he points out, is simply not a plausible account of normativity. The difference between the two accounts, then, is that the former, but not the latter, assumes that the person in question is practically rational.

Finally, he introduces the third grade of normativity, which he refers to as 'authoritative normativity'. The idea, he explains, ${ }^{41}$ is that morality has objective authority over us, in the sense that it explains why a 'rational person would take her moral beliefs appropriately into account in deciding how to live'. He distinguishes two different interpretations of this idea, namely (i) the authoritative reasons proposal and (ii) the closed question proposal. On the authoritative reasons proposal, the property of morality of being objectively authoritative explains why rational people actually pay attention to the demands of morality, that is, why morality motivates them:

\footnotetext{
${ }^{37}$ David Copp, Morality in a Natural World (Cambridge University Press 2007) ch 8.

38 ibid 257.

${ }^{39}$ ibid 258

${ }^{40}$ ibid.

${ }^{41}$ ibid 267.
} 
They pay attention, and they are motivated appropriately, because, to the extent at least that they are fully rational and thinking clearly, they understand that morality is a source of authoritative reasons, reasons of a kind that any rational person would take into account, just in virtue of being rational. ${ }^{42}$

On the closed question proposal, the property of morality of being objectively authoritative is meant instead to close the question, 'Why be moral?'. As Copp puts it: 'the question could not arise as a genuine practical question for any rational person who was thinking clearly about, and who understood the nature of, a requirement or ideal that has authoritative normativity. ${ }^{, 43}$

We have thus distinguished, in addition to the conceptions of justified and social normativity, discussed in Section 4, three grades of normativity of increasing stringency, namely (i) generic normativity, (ii) motivational normativity, and (iii) authoritative normativity. On my understanding, generic normativity is the weakest grade of normativity, social normativity is a bit stronger, motivational normativity is even stronger, and authoritative (or justified) normativity is the strongest grade; and the authoritative reasons proposal and the closed question proposal are two different ways of spelling out the import of the general idea of authoritative normativity. I find it natural to spell out the idea of justified normativity in terms of what Copp calls authoritative normativity, and I prefer to think of authoritative normative along the lines of the authoritative reasons proposal, because I find it illuminating to think of a standard that has authoritative normativity as a standard that provides a rational agent with authoritative reasons in the sense that a rational agent would take them into account just in virtue of being rational.

I shall not pursue the very difficult question about the precise import of the concept of authoritative normativity any further in this article. For not only do I find it very difficult to make progress here, I also believe that whether we choose to specify the notion of justified normativity in the one way or the other, most contemporary legal philosophers who debate the question of the normativity of law have, or would have if they thought about it, something like authoritative normativity in mind when they speak of legal normativity; and I shall therefore allow myself to simply assume in what follows that the question is whether law is necessarily normative in something like the sense of authoritative normativity spelled out along the lines of the authoritative reasons proposal.

One may, of course, ask whether we have good reason to think that either law or morality has, or could have, authoritative normativity. Copp, for example, does not believe that morality has it, ${ }^{44}$ and I assume this means that he does not believe law has it either. Like Copp, I doubt that morality has, or even could have, authoritative normativity, but I shall nevertheless assume in what follows, for the purposes of this article, that morality does, or at least could, have such normativity, and that law could have it, too - for, it seems to me, if I did not make this assumption, the very problem of the normativity of law, as I have explained it above, would vanish into thin air.

\footnotetext{
${ }^{42}$ ibid 261.

${ }^{43}$ ibid 262.

${ }^{44}$ ibid 280.
} 


\section{The theory of the basic norm}

As is well known, Kelsen conceives of law as a system of norms, arguing that a legal norm, $N_{1}$, is valid, that is, binding in something like the sense of authoritative normativity, if, and only if, it can be traced back to another and higher legal norm, $N_{2}$, that $N_{2}$ in turn is valid if, and only if, it can be traced back to yet another and higher legal norm, $N_{3}$, and that if one keeps tracing the validity of legal norms through the system in his way, one will finally arrive at the historically first constitution. ${ }^{45} \mathrm{He}$ maintains, in keeping with this, that the validity of law depends ultimately on the presupposition of the basic norm (Grundnorm), which can be formulated schematically as follows: 'Coercion is to be applied under certain conditions and in a certain way, namely, as determined by the framers of the first constitution or by the authorities to whom they have delegated appropriate powers. ${ }^{46}$

The presupposition of the basic norm, Kelsen explains, is necessary for anyone who wants to conceive of law as a system of valid norms, while remaining within the framework of legal positivism. The reason, of course, is that the separation thesis bars the legal positivist from grounding the validity of law in morality, say, by a reference to democracy or human rights, or, for that matter, to the will of God. In the words of Kelsen:

The ultimate hypothesis of positivism is the norm authorizing the historically first legislator. The whole function of this basic norm is to confer law-creating power on the act of the first legislator and on all the other acts based on the first act. To interpret these acts of human beings as legal acts and their products as binding norms, and that means to interpret the empirical material which presents itself as law as such, is possible only on the condition that the basic norm is presupposed as a valid norm. The basic norm is only the necessary presupposition of any positivistic interpretation of the legal material. ${ }^{47}$

So, as Kelsen sees it, the validity of law depends on the act of presupposing the basic norm, an act that one may or may not carry out, depending on whether one wishes to conceive of law as a system of valid norms or not. What this means is that although one may, one does not have to, presuppose the basic norm, which is to say that although one may, one does not have to, conceive of law as a system of valid norms. On this analysis, Kelsen points out, the basic norm plays only an epistemological - not a justificatory - role, and the validity (binding force, normativity) of law is conditional upon the presupposition of the basic norm. ${ }^{48}$

Kelsen is careful to point out that he is not introducing a new method into jurisprudence by introducing the theory of the basic norm, but is simply making explicit what is implicit in everyday legal thinking. As he explains, "[w]ith the doctrine of the basic norm, the Pure Theory analyses the actual process of the long-standing method of cognizing positive law, in an attempt simply to reveal the transcendental logical conditions of that method'. ${ }^{49}$ He means, I take it, that since one cannot derive an 'ought' from an 'is', a person who wants to arrive at a normative (or evaluative) conclusion, such as that one ought to obey the law, has to introduce a normative (or evaluative) premise, and that this premise is nothing other than the presupposed basic norm. Hence one must

\footnotetext{
${ }^{45}$ Kelsen, Introduction to the Problems of Legal Theory (n 7) 55-57, 63-65.

${ }^{46}$ ibid 57.

${ }^{47}$ Kelsen, General Theory (n 12) 116.

${ }^{48}$ Kelsen, Reine Rechtslehre (n 31) 224-5.

${ }^{49}$ Kelsen, Introduction to the Problems of Legal Theory (n 7) 58; General Theory (n 12) 116-17.
} 
attribute to lawyers, legal scholars, and others the presupposition of the basic norm - logically, if not psychologically.

I have just said that, on Kelsen's analysis, the normativity of law is conditional upon the presupposition of the basic norm. But this claim may be somewhat misleading. Let us turn to consider Joseph Raz's illuminating interpretation of the theory of the basic norm, which suggests a slightly different understanding of the theory.

\section{Detached normative statements}

Raz introduces the concept of the legal man - the legal man accepts the law of the land as his personal morality - and explains that, on Kelsen's analysis, legal scholars adopt the point of view of the legal man, albeit in a detached, not a committed, way. ${ }^{50}$ The reason is that legal scholars want to be able to conceive of law as a system of valid (binding) norms for the purely intellectual purpose of discussing its correct interpretation and application. As Raz puts it:

Legal science is not committed to regarding the law as just. It adopts this point of view in a special sense of 'adopt'. It is professional and uncommitted adoption. Legal science presupposes the basic normnot as individuals do - i.e. by accepting it as just - but in this special professional and uncommitted sense. ${ }^{51}$

To understand what Raz has in mind here, we need to relate the distinction between committed and detached legal statements to the distinction between internal and external legal statements. Whereas an internal legal statement is a first-order, normative (or evaluative) statement of law, an external legal statement is a second-order, descriptive statement about law; and whereas a committed statement is a statement made by someone who really means what he says, a detached statement is a statement made by someone who is speaking from a point of view that he may or may not accept.

We see here that a detached legal statement is an internal, albeit a detached, legal statement. ${ }^{52}$ As Raz points out elsewhere, ${ }^{53}$ to make a detached legal statement is not to make a conditional legal statement, such as 'If you want to achieve $Y$, you ought to do $X$ '. To make a detached legal statement is instead to state that you ought to do $X$, on the assumption that you want to achieve $Y$, without being committed to that assumption. The difference between a conditional legal statement and a detached legal statement, then, is that in the former case the assumption that you want to achieve $Y$ is part of the statement, whereas in the latter case it functions as a tacit presupposition. Clearly, this is not a substantive, but a semantic (or perhaps a pragmatic) difference, that is, a difference in the meaning (or use) of the two types of statement: whereas a conditional legal statement is descriptive, a detached legal statement is normative. As I have said (in Section 3), legal positivists need the idea of a detached legal statement in order to respect the separation thesis, if and insofar as they believe (as Raz and MacCormick do) that 'ought' has the same meaning in legal and moral contexts. As should be clear, the emphasis on detached, as

\footnotetext{
${ }^{50} \mathrm{Raz}$, The Authority of Law (n 3) 140-43.

${ }^{51}$ ibid $142-3$.

${ }^{52}$ According to Toh, Raz himself does not think of detached legal statements as internal statements: Toh, 'Raz on Detachment' (n 13) 408. Toh does not accept Raz's view, however, and neither do I.

${ }^{53}$ Joseph Raz, Practical Reasons and Norms (2nd edn, Princeton University Press 1990) 170-77.
} 
distinguished from committed, legal statements is in keeping with Kelsen's claim that the basic norm plays an epistemological, not a justificatory, role in the Pure Theory of Law.

What this means is that, on Raz's analysis, Kelsen does not conceive of the normativity of law as being conditional upon the presupposition of the basic norm, but as being unconditional when seen from a certain point of view, namely, the point of view of a person who adopts the basic norm, a point of view that one may or may not adopt as one sees fit. The difference between these two ways of conceiving legal normativity is thus the difference between (i) a conditionally normative, that is, descriptive, and (ii) a categorically normative, albeit detached, interpretation of legal statements. Kelsen's claim about the normativity of law, then, as interpreted by Raz, is that the normativity of law is to be found not in law itself, but in the characteristic practice of various legal actors of making normative but detached first-order claims of law, rather than conditional and descriptive second-order claims about law.

We see here that, on Raz's interpretation, Kelsen takes the problem of the normativity of law to be the problem of explaining the use of normative legal language by judges, attorneys, legal scholars, and others, and not (as most contemporary jurisprudents do) the problem of explaining the normativity of law, conceived as a necessary property of law itself. Having observed that both natural law theories and sanction-oriented theories have attempted to explain the normativity of law by showing that laws are valid reasons for action, Raz points out that there is also a third approach to the problem of the normativity of law, according to which the key to the problem is to see not that laws are valid reasons for action, but that people believe they are. ${ }^{54}$

We might say that, on Raz's interpretation, Kelsen offers a belief-based, not a validitybased, explanation of legal normativity. The distinction between validity-based and beliefbased explanations of legal normativity is important, (i) because it amounts to a distinction between two very different questions, mentioned above in the Introduction, namely, between the question of how to account for the normativity of law, conceived as a necessary property of law, and the question of how to account for the use of normative legal language on the part of judges, attorneys, legal scholars, and others, and (ii) because it makes it clear that Kelsen's attempt to account for the normativity of law by means of the theory of the basic norm would not be as obviously misguided as it is commonly thought to be ${ }^{55}$ if it were aimed at explaining not the normativity of law, conceived as a necessary property of law, but the use of normative legal language by various legal actors. For whereas it is difficult to see how a presupposition on the part of, say, judges or legal scholars could explain the normativity of law, it is not difficult to see how such a presupposition (even if implicit) could explain the use of normative legal language on the part of judges, attorneys, legal scholars, and others. But, as I have said, the question that concerns us in this article is not Kelsen's question, but the question of whether we can account for the normativity of law, conceived as a necessary property of law, within

\footnotetext{
${ }^{54}$ ibid 170.

${ }^{55}$ See e.g. Carlos E Alchourrón and Eugenio Bulygin, Normative Systems (Springer 1971) 73; Robert Alexy, The Argument from Injustice: A Reply to Legal Positivism (Oxford University Press 2002) 95-116; Leslie Green, 'Positivism and Conventionalism' (1999) 12 Canadian Journal of Law and Jurisprudence 35, 36; Andrei Marmor, 'The Conventional Foundations of Law' in Stefano Bertea and George Pavlakos (eds), New Essays on the Normativity of Law (Hart Publishing 2010) 143-57, 146; Karl Olivecrona, 'Realism and Idealism: Some Reflections on the Cardinal Point in Legal Philosophy' (1951) 26 New York University Law Review 120, 127-8.
} 
the framework of legal positivism, that is, whether we can offer a validity-based account of the normativity of law within the framework of legal positivism.

\section{Conventionalism and normativity: Gerald Postema}

We have seen (in Section 4) that Hart objects to Austin's command theory of law, that it cannot account for the normativity of law, and that what is missing in Austin's theory is the idea of a rule. And we have seen that, on Hart's analysis, the foundation of the normativity of law is to be found in the rule of recognition. As Hart sees it, the rule of recognition qualifies as a social rule because it satisfies the criteria in his general theory of social rules, sometimes referred to as the practice theory of rules. ${ }^{56}$ Under this theory, there is a social rule, $R$, in a community, $S$, if, and only if, the members of $S$ (i) display a certain pattern of behaviour that corresponds to $R$ (the external aspect) and also (ii) hold that they ought to act in this particular way (the internal aspect). And since it is clear from Hart's account ${ }^{57}$ that legal officials must view the rule of recognition as a 'common standard of correct judicial decision, and not as something which each judge obeys merely for his part only', we may describe the rule of recognition as a conventional rule. ${ }^{58}$

As we have also seen (in Section 4), Hart appears to operate with the conception of social normativity, according to which a standard is a social norm only if and in so far as it is socially upheld as a binding standard and the society involved exerts pressure on people to whom the standard applies to conform to it. But we have also said that the conception, or grade, of normativity that is interesting in this context is not social, but authoritative normativity. And this would seem to mean that Hart's thoughts on social rules and the normativity of law are not relevant to our discussion of the normativity of law, which thus centres on the idea of authoritative normativity.

However, some authors, who appear to have something like justified normativity in mind, have argued that if we can only refine Hart's practice theory of rules, we may be able to account for the normativity of law. Gerald Postema, for example, proposes to

shift the focus of the [conventionalist] doctrine away from the regularities of behaviour and attitude which Hart believes 'constitute' the rule of recognition to the strategic context, the context of practical reasoning, in which such regularities take on normative significance. ${ }^{59}$

On his analysis, a regularity, $R$, in the behaviour of persons in a population, $P$, in a recurring situation, $S$, is a convention if, and only if, in any instance of $S(1)$ it is common knowledge in $P(a)$ that there is in $P$ general conformity to $R,(b)$ that most members of $P$ expect most other members of $P$ to conform to $R,(c)$ that almost every member of $P$ prefers that any individual conform rather than not conform to some regularity of behaviour in $S$, given general conformity to that regularity, and $(d)$ that almost every member of $P$ prefers general conformity to some regularity rather than general non-conformity; and (2) that part of the reason why most members of $P$ do conform to $R$ in $S$ is that $(1 a)$ to

\footnotetext{
${ }^{56}$ See e.g. Raz, Practical Reasons and Norms (n 53) 50-58.

${ }^{57}$ Hart, The Concept of Law (n 3) 112.

${ }^{58}$ On this, see HLA Hart, The Concept of Law (2nd edn, With a Postscript Edited by Penelope A Bulloch and Joseph Raz, Oxford University Press 1994) 255.

${ }^{59}$ Gerald J Postema, 'Coordination and Convention at the Foundations of Law' (1982) 11 The Journal of Legal Studies 165 , 167.
} 
(1d) obtains. ${ }^{60}$ And, as Postema sees it, a person who fails to do his part in such a conventionally defined joint effort acts unfairly, and this means that at least in some cases he may have an obligation to conform to the convention. ${ }^{61}$ On the basis of this account of coordination conventions, Postema then argues that we have reason to view the rule of recognition as precisely such a conventional rule aiming at coordinating the behaviour of officials and citizens that may give rise to a judicial obligation (or a duty) to identify the law in a certain way and to follow the law thus identified. ${ }^{62}$

To follow a convention, Postema explains, is to engage in a common form of behaviour and (in doing so) to meet the expectations of others, while having expectations oneself regarding the behaviour of the others, which they meet. And, he adds, to have such expectations in such a context is reasonable:

The fact is, others expect one to conform in part because they know that one expects them to conform, and they have relied (or will rely), perhaps to their detriment, on this expectation. And, in the context, such expectations seem entirely reasonable. ${ }^{63}$

But, Postema continues, not all expectations, not even all reasonable expectations, on which there is detrimental reliance, generate obligations. On his analysis, ${ }^{64}$ for obligations to arise, (at least) one of two conditions must be satisfied: either (i) detrimental reliance on the expectations must be, in a sufficiently broad sense, induced, or else (ii) the context in which the expectations arise and are sustained must be closely analogous to a cooperative enterprise for mutual benefit in which considerations of fair play require conformity'.

It is not easy to say precisely in what situations a person, $A$, can be said to have been induced by another person, $B$, to expect $B$ (or $C$ or $D$, etc.) to do $X$ in such a way that $A$ is entitled to rely on that expectation. Postema offers the example that $B$ promises $A$ to behave in a certain way and another example involving a truck driver whose vehicle stalls on a two-lane road and who exits the truck and waves traffic around it. ${ }^{65}$ In the latter situation, Postema reasons, the truck driver induces other drivers to expect that there will be no oncoming traffic that they cannot see and to rely on this expectation. He adds that it is not necessary that the truck driver actually intends the drivers to rely on his guidance; it is sufficient that 'his actions could reasonably be interpreted as intended to induce expectations and reliance on them'. ${ }^{66}$

The other alternative, as we have seen, is that conventions, which arise in a strategic social context, resemble a cooperative enterprise for mutual benefit of a type that attracts the so-called doctrine of fair play. As Postema explains, given a situation in which there is a 'rich pattern of interaction and interdependent regularities of behaviour have developed over time' and in which the participants have voluntarily accepted benefits and are also motivated to free-ride, one may well argue that a person who fails to do his part in a

\footnotetext{
${ }^{60}$ ibid 176. One may well wonder what requirement (c) adds to requirement (d). If (as (d) has it) almost every member of $P$ prefers general conformity to some regularity, $R$, rather than general non-conformity, does it not follow (as (c) has it) that almost every member of $P$ prefers that any individual conform rather than not conform to $R$ ?

${ }^{61}$ Postema, 'Coordination and Convention' (n 59) 182.

62ibid 195-6, 199.

${ }^{63}$ ibid $179-80$.

${ }^{64}$ ibid 180.

65 ibid $180-81$.

${ }^{66}$ ibid 181.
} 
conventionally defined joint effort is acting unfairly, and that therefore he has an obligation to conform. ${ }^{67}$

I agree with Postema that both alternatives - (i) and (ii) - may generate obligations, in the case of (ii) provided that the stakes are sufficiently high. But, one wonders, how does all this apply in a legal context? Postema's idea is that the rule of recognition is a conventional rule in the sense explained, and that it generates obligations on the part of legal officials to go about identifying the law in a certain way (by consulting the sources of law constituted by and identified in the rule of recognition) and to follow the law thus identified. He maintains, more specifically, that legal thinking typically aims at coordinating the actions of officials and lay persons, and that it is this feature of legal thinking that is capable of generating an obligation for legal officials both to identify the law in a certain way and to follow the law thus identified. ${ }^{68}$

To explain how this can be so, he introduces a distinction between (a) first-, $(b)$ second-, and $(c)$ third-level coordination in law, where $(a)$ is coordination between citizens, $(b)$ is coordination between citizens and officials, and $(c)$ is coordination between officials ${ }^{69}$ and argues that

there are significant second- and third-level coordination problems in a community living under law ... [and] that it is legitimate to describe social interaction (and the structure of practical reasoning) within the context of law as a set of complex and persisting coordination problems. $^{70}$

Postema reasons that if the justifications of decisions on the part of the officials depend in an important sense on the beliefs, attitudes, or expectations of the citizens, namely, in the sense (as we shall see) that such justifications must take into account the way the relevant rules and decisions function in the practical reasoning of the citizens, then the understanding of the law on the part of the officials will depend on the understanding of the law and the expectations of the citizens in the sense that is necessary, but not sufficient, to establish that the rule of recognition is a coordination convention. But, as he notes, ${ }^{71}$ it is tempting to object to this, that while it is plausible to hold that the understanding of the law on the part of the citizens will depend on the understanding of the law and the expectations of the legal officials, it is less plausible to maintain that the understanding of the law on the part of the latter will depend on the understanding of the law and the expectations of the former. He rejects this objection, however, ${ }^{72}$ arguing that judges must presumably be able to justify their decisions about the validity or interpretation of legal rules, and that if such a defence could not depend in any important way on the beliefs, attitudes, or expectations of law-subjects', ${ }^{73}$ judges would have to appeal either (i) to some platonic world of law (metaphysical realism), or else (ii) to the attitudes, beliefs, etc., of other officials along the lines of 'law is what the officials say is law' (metaphysical anti-realism). But, he points out, accepting (i) would contradict the social thesis and accepting (ii) would contradict the normativity thesis.

\footnotetext{
${ }^{67}$ ibid 182.

${ }^{68}$ ibid 187.

${ }^{69}$ ibid 182-97.

${ }^{70}$ ibid 183.

${ }^{71}$ ibid 190-91.

${ }^{72}$ ibid 190-92.

${ }^{73}$ ibid 190.
} 
I agree with Postema that accepting (i) would be to flatly contradict the social thesis. I am not, however, convinced that accepting (ii) would contradict the normativity thesis, or that it would be a problem if it did. First, my own view is that the normativity thesis simply does not hold, and that the analyst should not presuppose so strongly that it holds, that he is willing to reject an otherwise attractive argumentative move (in this case, accepting alternative (ii)) for the sole reason that doing so would undermine that presupposition. For this is to assume what should be proved, namely, that law is necessarily normative (in the sense of authoritative authority). Second, assuming with Postema that the normativity thesis does hold, I would argue that choosing (ii) would not contradict the normativity thesis. Postema's idea is that officials who view legal norms as aiming to guide the behaviour of the law-subjects, while ignoring the way they function in the practical reasoning of the same law-subjects, will have to regard their relation to the citizens as akin to that of the master to his dog, or to that of 'man against nature', that is, to ignore the fact that the citizens can and often do adopt the internal point of view with respect to legal norms, that law is a matter of regulating the behaviour of rational beings, ${ }^{74}$ and that this is precisely to undermine the normativity thesis. As he says, ${ }^{75}$ while there may be people in power who do treat the citizens in such a disrespectful way, they cannot be said to do so within the framework of law.

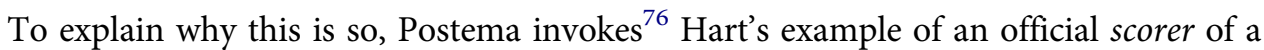
game, ${ }^{77}$ whose activity presupposes, in order to be intelligible to the players of the game, that an unofficial scorer (say, a player) could do precisely what the scorer does in his official capacity - if this were not possible, the players could not really be said to understand the scorer's activity and so, Postema, following Lucas, ${ }^{78}$ appears to be saying, the scorer would not really be a scorer. By the same token, Postema reasons that an official's decisions will be intelligible to the law-subjects and so will be normative or, if you prefer, will be legal decisions, only if a lay person could in principle do what the official does in his official capacity and in that sense understand it, that is, only if the official in his decisionmaking takes into account the understanding of the law and the expectations of the lawsubjects.

Postema concludes that this means that the understanding of the law by officials and citizens are interdependent to an important degree. ${ }^{79} \mathrm{He}$ then argues that since this is so and since the preferences of the parties have the structure characteristic of coordination problems, we have reason to view the rule of recognition as precisely such a conventional rule aiming at coordinating the behaviour of officials and citizens that may give rise to an obligation (or a duty):

On this view, conventional judicial duties are genuine duties, not just forms of behaviour which people may believe to be obligatory. Because they rest on an important (albeit limited) concern for fairness, they belong to a species of moral duty. ${ }^{80}$

\footnotetext{
$74_{\text {ibid }} 187$.

${ }^{75}$ ibid 191.

76ibid 191-2.

${ }^{77}$ For Hart's discussion of the scorer and the game 'scorer's discretion', see Hart, The Concept of Law (n 3), 139-41. Postema also draws on Lucas's discussion of the scorer in JR Lucas, 'The Phenomenon of Law' in PMS Hacker and J Raz (eds), Law, Morality, and Society: Essays in Honour of HLA Hart (Oxford University Press 1977) 85-98, 93-95.

${ }^{78}$ Lucas, 'The Phenomenon of Law' (n 77).

${ }^{79}$ Postema, 'Coordination and Convention' (n 59) 189-90.

${ }^{80}$ ibid 199 (footnote omitted).
} 
The important thing about the rule of recognition, on this analysis, Postema points out in conclusion, is not the underlying reasons for accepting it, but the fact of acceptance itself. The normative force of the rule of recognition, he explains, depends on the success of the rule in coordinating the activities of officials and lay persons:

Judges need not believe, nor need it be true, that the existing rule of recognition is the ideally best such rule. They may believe, and have good arguments to show, that it is; they may also believe, and have good arguments to show, that some other rule would be better, more just, or the like. But as long as the existing rule succeeds, and alternative rules cannot promise success, and as long as achieving coordination is at least minimally desirable, the existing rule will continue to generate (prima facie) obligations on the part of officials to conform to it. ${ }^{81}$

I find Postema's claim that the rule of recognition is a coordination convention in the sense explained highly interesting and not without plausibility. I see a couple of difficulties, however. First, it is not clear to me that the legal officials and the citizens are really involved in a coordination enterprise in the first place. Postema maintains, as we have seen, (i) that the understanding of the law on the part of the citizens depends on the understanding of the law and the expectations of the officials, and (ii) that the understanding of the law on the part of the latter depends on the understanding of the law and the expectations of the former; and he argues as regards (ii) that if the decision-making on the part of the officials did not take into account the way legal rules and decisions function in the practical reasoning of the citizens, it would not be intelligible and so would not be legal decision-making at all. But while it may be a plausible normative requirement, that legal officials be able to justify (at least in principle) their laws and decisions to the citizens, it is - despite the scorer example - not clear to me that it is a conceptual requirement, so that a failure to meet it would result in something that did not qualify as a legal decision.

Second, assuming that Postema is right that officials and citizens are indeed involved in such a coordination game, we may ask, does it really follow from this that officials have an obligation (or a duty) to identify the law in a certain way and to follow the law thus identified? I am inclined to think it does, though one may well wonder whether all the elements of Postema's account of obligations can be properly described as being exclusively social in character. For it seems to me that both alternatives (i) and (ii) considered above involve reference to moral principles that are independent of the relevant social facts. As Stefano Bertea points out, discussing not legal conventionalism, but law as a shared cooperative activity, the obligation, if there is one, presupposes either the doctrine of fair play or else a moral principle requiring you to honour the expectations you have led others to have regarding your own behaviour and commitment to the practice. ${ }^{82}$ Such evaluative considerations go beyond the relevant social facts, however, and this in turn means that Postema's account is not, strictly speaking, in keeping with the social thesis (in either its weak or its strong form).

Let us, however, assume that Postema's account is not vulnerable to this objection. One may then wonder why officials, but not citizens, acquire an obligation to identify the law in the relevant way and to follow it, given that, on Postema's analysis, both officials and citizens are involved in a cooperative enterprise for mutual benefit. The reason, Postema

\footnotetext{
${ }^{81}$ ibid 199-200.

${ }^{82}$ Stefano Bertea, 'Law, Shared Activities, and Obligation' (2014) 27 Canadian Journal of Jurisprudence 357, 372-5.
} 
explains, is that one important condition for the applicability of the doctrine of fair play is not satisfied, namely, that the parties to the cooperative enterprise for mutual benefit have in some sense voluntarily accepted the benefits. ${ }^{83}$ As he notes, in the case of the law, the citizens will get whatever benefits the law provides whether they want them or not.

This sounds right to me. But this explanation cannot account for cases where the obligation is grounded not in the doctrine of fair play, but in induced, detrimental reliance on expectations. I cannot see that Postema explains why obligations grounded in the latter way should apply only to officials. He might, of course, reason that while the officials are under an obligation because they have induced the citizens to rely on their expectations, the citizens are not under such an obligation because they have not induced the officials to rely on their expectations. I am not, however, convinced that this line of argument would be compatible with what Postema says about the understanding of the law on the part of the citizens being dependent on the understanding of the law and the expectations of the legal officials and the understanding of the law on the part of the officials being dependent on the understandings of the law and the expectations of the citizens. If such dependence goes both ways, why should not the inducement go both ways?

If Postema is right, however, we must conclude that the rule of recognition, conceived as a coordination convention, generates obligations on the part of the officials, but not on the part of the citizens, to identify the law in a certain way and to follow the law thus identified. To show that law is necessarily normative for legal officials is, however, a considerable distance away from showing that law is necessarily normative for officials and citizens alike. And since the question of the normativity of law, which is what concerns us in this article, is the question of whether law is necessarily normative across the board, I conclude that Postema's fine analysis does not justify an affirmative answer to this question.

\section{Conventionalism and normativity: Andrei Marmor}

Andrei Marmor, too, believes that the idea of a social convention can play an important role in an account of the normativity of law. ${ }^{84}$ Marmor, who speaks about the rules of recognition in the plural, shares Hart's and Postema's view that these rules are conventional rules, and he also appears to share Kelsen's and Postema's view of what normativity is, namely, something like authoritative normativity. He maintains, however, that the rules of recognition are best understood as constitutive - as distinguished from coordinative conventions and argues that this means that the normativity of law can only be conditional upon a wish on the part of the subjects of law to 'play the legal game'.

Marmor lays down the following three - individually necessary and jointly sufficient conditions for the existence of conventional rules of recognition: ${ }^{85}$

(i) There is a group of people, $P$, whose members normally follow the rules of recognition, $R R$, in circumstances, $C$.

(ii) There is a set of reasons, $A$, for the members of $P$ to follow $R R$.

\footnotetext{
${ }^{83}$ Postema, 'Coordination and Convention' (n 59), 195-6.

${ }^{84}$ Marmor, 'The Conventional Foundations of Law' (n 55) 143-57.

${ }^{85}$ ibid 149.
} 
(iii) There is at least one other potential set of rules, $S R$, such that if the members of $P$ had actually followed $S R$ instead of $R R$ in $C$, then $A$ would have been sufficient for the members of $P$ to do so.

We see that, on Marmor's analysis, a rule, $R_{1}$, is a conventional rule if, and only if, (i) the members of a group of people follow $R_{1}$, (ii) they have reasons, $A$, to follow $R_{1}$, and (iii) $A$ would also have been sufficient for them to follow another, similar rule, $R_{2}$. Condition (i) makes it clear that the members of the group must, on the whole, follow the rule, so that not every member must follow the rule on every occasion. Condition (ii), as I understand it, means that there are reasons for the members of the group to follow the rule, though the group members do not have to follow the rule because of those reasons or, indeed, be aware of the reasons at all. ${ }^{86}$ As Raz might put it, while they must conform to the rule, they need not comply with it. ${ }^{87}$ And condition (iii) makes it clear that conventions are arbitrary, in the sense that a different rule than the one at hand might have fulfilled the function equally well. What is important is that there is a rule, not its specific content.

Marmor notes that some authors have objected to the view that the rules of recognition are conventional, that it is difficult to see how a mere convention could give rise to an obligation. ${ }^{88} \mathrm{He}$ cites an article by Leslie Green, in which the author says that the view (Hart's view) that the rule of recognition is a 'mere' convention 'continues to sit uneasily with any notion of obligation'. ${ }^{89}$ And he (Marmor) takes the gist of Green's objection to concern the above-mentioned arbitrariness of conventions: 'if the rules of recognition are arbitrary in the requisite sense, how can we explain the fact that they are supposed to obligate judges and other legal officials to follow them? ${ }^{90}$ His answer to this question suggests that he considers the objection to be well founded, arguing as he does that we have to make a distinction between the legal obligation to follow the rules of recognition and the moral obligation, if there is one, to follow these rules:

The rules of recognition, like the rules of chess, determine what the practice is. They constitute the rules of the game, so to speak. Like other constitutive rules, they have a dual function: they both determine what constitutes the practice, and prescribe modes of conduct within it. The legal obligation to follow the rules of recognition is just like the chess players' obligation, say, to move the bishop diagonally. Both are prescribed by the rules of the game. What such rules cannot prescribe, however, is an 'ought' about playing the game to begin with ... the normativity of constitutive conventions is always conditional. Conventional practices create reasons for action only if the relevant agent has a reason to participate in the practice to begin with. And that is true of the law as well. If there is an 'ought to play the game', so to speak, then this ought cannot be expected to come from the rules of recognition. The obligation to play by the rules, that is, to follow the law, if there is one, must come from moral and political considerations. The reasons to obey the law cannot be derived from the norms that determine what the law is. ${ }^{91}$

Marmor offers three distinct arguments in support of the claim that the rules of recognition, conceived as constitutive conventions, cannot also be coordination conventions.

\footnotetext{
${ }^{86}$ On this, see Andrei Marmor, Social Conventions (Princeton University Press 2009) 5-6.

${ }^{87}$ Raz, Practical Reasons and Norms (n 53) 178.

${ }^{88}$ Marmor, 'The Conventional Foundations of Law' (n 55) 15.

${ }^{89}$ Leslie Green, 'The Concept of Law Revisited' (1996) 94 Michigan Law Review 1687, 1697.

${ }^{90}$ Marmor, 'The Conventional Foundations of Law' (n 55) 151.

${ }^{91}$ ibid 152 (footnote omitted).
} 
Specifically, he objects that the view that the rules of recognition are coordination conventions (i) misses the point that the rules of recognition constitute what law is, (ii) is not easy to reconcile with the political importance of these rules, and (iii) blurs the distinction between the question of what law is and the question of what counts as law in a particular legal order. ${ }^{92}$ I am not, however, convinced by his argumentation. Let me explain why.

Marmor reasons, on the first count, that the rules of recognition have a constitutive function in the sense that they determine what counts as law, that coordination conventions do not usually fulfil a constitutive function, that we cannot even begin to coordinate the behaviour of judges if we do not already see them as judges, and that coordination conventions cannot fulfil such a constitutive function.

But, to begin with, even though coordination conventions do not usually fulfil a constitutive function, this does not mean that they never fulfil such a function, still less that they cannot do so. For example, just as a duty-imposing norm can also be a competence norm (or, if you will, a power-conferring norm), on the grounds that it confers competence on the members of a class of persons, $A$, by virtue of imposing a duty on the members of another class of persons, $B$, to act in accordance with, say, the norms issued or the decisions made by the members of $A,{ }^{93}$ a coordination convention can also be a constitutive convention, on the grounds that it confers legal power to issue norms or make decisions on the members of $A$ by imposing a duty on the members of $B$ (assuming, of course, that it can impose a duty) to act in accordance with the norms issued or the decisions made by the members of $A$.

And while I agree with Marmor that we cannot even begin to coordinate the behaviour of judges if we do not already see them as judges, I find the idea that it is the rules of recognition that make a person a judge ('constitute a judge') somewhat problematic. The reason is that, on Hart's analysis, it is the behaviour precisely of judges (together with the internal point of view) that constitutes the rules of recognition. More specifically, in order to have rules of recognition, we need to have judges; in order to have judges, we need to have rules of adjudication; and in order to have rules of adjudication, we need to have rules of recognition. If this is so, we seem to have here a vicious circle, ${ }^{94}$ and if it is a vicious circle, it cannot be the case, on Hart's theory, that it is the rules of recognition that make a person a judge.

But perhaps there is a way out for Marmor. Jules Coleman has argued that we may imagine a situation in which some individuals choose to have their behaviour guided by a certain rule, and that this situation develops with time into a legal system. ${ }^{95}$ As Coleman says,

[i]f that rule takes hold in the sense of establishing membership criteria in a system of rules, and if those rules are complied with generally, and if institutions of certain types are then created, and so on, it is fair to say that a legal system exists. ${ }^{96}$

\footnotetext{
${ }^{92}$ ibid 153-4.

${ }^{93}$ On this, see Torben Spaak, The Concept of Legal Competence (Dartmouth 1994) 171-3; 'Norms that Confer Competence' (2003) 16 Ratio Juris 89, 94-97.

${ }^{94}$ On this, see Neil MacCormick, HLA Hart (Stanford University Press 1981) 108-109.

${ }^{95}$ Coleman (n 1) 100-101.

${ }^{96}$ ibid.
} 
And if a legal system does exist, the rule in question will be the rule of recognition of the system and the individuals will be officials of the system, even though the rule was not the rule of recognition and the officials were not officials in the beginning. As Coleman puts it,

[t]hey are, in a sense, officials in virtue of that rule, but they are not officials prior to it (in either the factual or the logical sense). Their behaviour makes the rule possible; but it is the rule that makes them officials. ${ }^{97}$

If Coleman is right, as I think he is, we must conclude that the purported vicious circle is, after all, not a vicious circle. Nevertheless, I believe, as I have said, that coordination conventions can fulfil a constitutive function, and if Coleman is right, they can also 'constitute a judge'.

Marmor argues on the second count that since the rules of recognition are often politically important and since it is difficult to see how coordination conventions - which are necessarily arbitrary - can be politically important, the rules of recognition cannot be coordination conventions. And he rightly points out that it matters to us who makes the law (politicians, judges, private parties, etc.) and infers that this means that the question of who makes the law cannot be a matter of coordination. I do not, however, think it is difficult to see how coordination conventions can be politically important. First, on Marmor's analysis, as we have seen, we may view a given coordination convention, $C_{1}$, as a means to a political goal, say, traffic safety, while recognising that conventions $C_{2}$ and $C_{3}$ might have been equally well suited to bring about that goal. If $C_{1}$ serves the relevant political goal, then it does not matter that $C_{2}$ and $C_{3}$ might have done an equally good job of serving that goal. $C_{1}$ is in any case politically important. For example, the convention in a certain country, say, Sweden, that we drive on the right-hand side of the road is arbitrary in the sense that we might equally well have been driving on the left-hand side (in fact, we did until 1 September 1967). But this hardly means that the convention is not politically (or morally) important, does it? Second, even if matters of pure coordination could not be politically important, there is, as I have said, the possibility that the rules of recognition are both constitutive and coordinative. And it is not difficult to see that constitutive conventions can be politically important.

Marmor argues, on the third count, that the view under consideration makes it unclear just how the rules of recognition relate to the concept of law. He maintains, as we have seen, that it is typically the case that we have independently of the relevant convention (the concept of) the activity that the convention is meant to coordinate, and that this follows from the reason for having a coordination convention in the first place, namely, that there is an activity that needs coordination, that there is a coordination problem that needs to be solved. As he puts it, 'without the social conventions that constitute ways of making law and recognising it as such, it is difficult to imagine what kind of concept of law we could possibly have'. ${ }^{98}$

His idea, as I understand it, is that if the rules of recognition are coordination conventions and thus not also constitutive conventions, we have no explanation of what concept of law we have, or of why we have the concept of law that we do. For it is the rules of recognition that supply us with an answer to these questions. If, however, the rules of

\footnotetext{
${ }^{97}$ ibid.

${ }^{98}$ Marmor, 'The Conventional Foundations of Law' (n 55) 154.
} 
recognition may be both coordination conventions and constitutive conventions at the same time, in the sense explained above, Marmor simply overshoots the mark. So, on my view, the rules of recognition could constitute the concept of law precisely because they are not only coordination conventions, but also constitutive conventions.

Let us, however, suppose that Marmor is right that the rules of recognition are constitutive conventions and nothing more, and that this means that the normativity of law can only be conditional upon the existence of moral reasons to play the legal game. My objection will then be that Marmor's claim is not very novel. For it seems to be in substance, if not in form, the same as Kelsen's claim - put forward by Kelsen already in $1925^{99}$ and repeated in his later books ${ }^{100}$ - that from the point of view of legal positivism, the normativity of law can only be conditional upon the presupposition of the basic norm, or, if you prefer, seen from the point of view of someone who adopts the basic norm. The idea of a constitutive convention is, to be sure, novel in this context, but it does not add much to the substance of Kelsen's claim about the normativity of law.

Given that Marmor's position on the question of the normativity of law is so similar to Kelsen's, it is interesting to note that Marmor objects that not much is explained by the presupposition of the basic norm: 'Instead of telling us something about the foundations of the basic norm, Kelsen simply invites us to stop asking. ${ }^{101}$ But, as we have seen, whereas Kelsen appears to be offering a belief-based, not a validity-based, account of legal normativity (see Section 6 above), Marmor clearly has in mind a validity-based, not a belief-based, account. And, as I have said, while it is difficult to see how a presupposition on the part of, say, judges or legal scholars could explain the normativity of law, conceived as a necessary property of law, it is not difficult to see how such a presupposition (even if implicit) could explain the use of normative language on the part of those who make the presupposition. Kelsen thus appears to have succeeded in answering his own question, even if he did not succeed in answering Marmor's question. I agree, however, with (what I take to be) Marmor's view, that Marmor's question is more interesting.

\section{Conditional (or point-of-View) normativity and the positivism/ non-positivism debate ${ }^{102}$}

I believe the discussion so far suggests the following two general conclusions. First, to say that the normativity of law is conditional upon the presupposition of the basic norm, or some such idea, is simply to say that law is not necessarily normative at all, and this raises the question why we should want to say at all that the normativity of law is conditional, or that law is normative when seen from a point of view that one may or may not adopt as one sees fit. Could we not with equal justification say that the normativity of the act of running from a house on fire is conditional upon a will to survive, or that this act is normative when seen from a certain point of view, namely, the point of view of someone who wishes to survive? Sure we could, but saying so would be to make a banal - and therefore confusing - claim. Hence I conclude that we can do without the idea of conditional

\footnotetext{
${ }^{99}$ Hans Kelsen, Allgemeine Staatslehre (Österreichische Staatsdruckerei 1993) 251 (first published 1925 by Julius Springer).

${ }^{100}$ See e.g. Kelsen, Reine Rechtslehre (n 31); Introduction to the Problems of Legal Theory (n 7); General Theory (n 12).

${ }^{101}$ Marmor, 'The Conventional Foundations of Law' (n 55) 146.

${ }^{102}$ Most of the text in this section can be found, more or less verbatim, in Torben Spaak, 'Plans, Conventions, and Legal Normativity' (2012) 3 Jurisprudence 509.
} 
normativity, or normativity from a point of view, in our inquiries into the nature of law. Of course, as I have said above, if we follow Raz (and Kelsen, if Raz is right) and take the question of the normativity of law to be the question of whether we can account for the use of normative legal language on the part of judges, attorneys, legal scholars and others, the idea of normativity from a point of view (or the idea of conditional normativity) may be of considerable interest. For, as I have said twice above, whereas it is difficult to see how the presupposition of the basic norm on the part of, say, judges could explain the normativity of law, it is not difficult to see how such a presupposition could explain the use of normative language on the part of those who make the presupposition.

Second, it seems to me that the debate about the normativity of law, conceived as a necessary property of law, is in substance, if not in form, more or less identical to the old debate between positivists and non-positivists, to use Robert Alexy's terms, ${ }^{103}$ about the existence of a necessary connection between law and morality. The main difference between the two debates is that in the debate about the normativity of law some legal positivists are now attempting to conquer a part of non-positivist (natural law) territory by adopting a position that is, or at least used to be considered, a non-positivist (or a natural law) position. If, however, only morality can have authoritative normativity, and if legal positivists insist on the separation thesis, then it clearly follows from the theory of legal positivism that law is not, and cannot be, necessarily normative. In light of this, the natural conclusion is that the question of the normativity of law, conceived as a quest for necessary properties of law and considered within the framework of legal positivism, is not an open, and therefore not a very interesting, legal-philosophical question.

As I see it, the important question for a legal positivist is whether a given legal order (or legal system) is in fact normative, in roughly the sense of authoritative normativity, and to determine whether this is so, one needs to consider the content and the administration of this legal order. For example, is the law, on the whole, a product of legislation enacted by a democratically elected parliament, is the content of the law morally satisfactory, and do judges and other legal officials act in accordance with the ideal of the Rechtsstaat (or the rule of law)? But this is hardly surprising, is it? Legal positivists have always said that legal rights and duties are not necessarily moral rights and duties, and that to determine whether any given legal right or duty is also a moral right or duty, or, if you prefer, whether we have an obligation to obey the law, we have to consider the content and administration of the law. ${ }^{104}$ They should therefore say that legal rights and duties are not necessarily normative in the sense of authoritative normativity, and that to determine whether any given legal right or duty is in fact normative (in this sense), we have to consider the content and administration of law.

\section{Acknowledgements}

I would like to thank Uta Bindreiter, Brian Bix, Åke Frändberg, Jaap Hage, Jens Johansson, Francisco Laporta, Thomas Mautner, Dennis Patterson, Gerald Postema, Paolo Sandro, and Antonia Waltermann for helpful comments on earlier versions of the article. I would also like to thank

\footnotetext{
${ }^{103}$ Robert Alexy, Begriff und Geltung des Rechts (2nd edn, Verlag Karl Alber 1994) 3-4 (first published 1992).

${ }^{104}$ See e.g. Green, 'Positivism and Conventionalism' ( $\left.\mathrm{n} 55\right)$ 35; Kelsen, General Theory (n 12), 60; Hart, Essays on Bentham (n 13), 127-8, 264-8; MacCormick, 'Comments' (n 14) 107-108.
} 
the participants in the workshop on conventionalism and legal normativity at the Legal Theory Festival at Edinburgh University School of Law on 29 May 2014, especially my discussant, Claudio Michelon, for helpful comments on an even earlier version of the article. In addition, I would like to thank Lars Bergström for discussing with me various questions concerning normativity and Robert Carroll for checking my English. As always, the responsibility for any remaining errors and imperfections in the article rests with the author alone. 